\title{
Effects of the 2008 Financial Crisis on the Determinants of Foreign Direct Investments in the West African Economic and Monetary Union (WAEMU): A Panel Data Approach
}

\author{
Tibi Didier Zoungrana1, Daouda Lawa tanToé2 \\ ${ }^{1}$ Department of Economics, Université Ouaga II, Ouagadougou, Burkina Faso \\ ${ }^{2}$ Université Aube Nouvelle, Ouagadougou, Burkina Faso \\ Email: zoungranadidier@yahoo.fr, lilekans@yahoo.fr
}

How to cite this paper: Zoungrana, T.D. and tanToé, D.L. (2018) Effects of the 2008 Financial Crisis on the Determinants of Foreign Direct Investments in the West African Economic and Monetary Union (WAEMU): A Panel Data Approach. Modern Economy, 9, 1729-1746.

https://doi.org/10.4236/me.2018.911109

Received: April 11, 2018

Accepted: November 10, 2018

Published: November 13, 2018

Copyright $\odot 2018$ by authors and Scientific Research Publishing Inc. This work is licensed under the Creative Commons Attribution International License (CC BY 4.0).

http://creativecommons.org/licenses/by/4.0/

\begin{abstract}
This article analyzes through a panel data analysis covering the period 1994 to 2016, the effects of the 2008 financial crisis on the determinants of Foreign Direct Investment in the West African Economic and Monetary Union (WAEMU). From the analysis, it turns out that this crisis has strongly impacted FDI's determinants in the union. In fact, as consequence, it created a much more infatuation of resource-seeking investors in spite of market-seeking investors. This result shows that those countries can still attract investors even in time of crisis if they have tremendous natural resources, which makes the protection of these resources very important. In addition, we can notice that after the crisis, the stability in the region became an important decisional variable for foreign investors. That points out the importance of promoting a good political governance. Furthermore, the study has also shown that the financial crisis has been a stepping corner for the emergence of a third type of investors in the region (efficiency seeking investors).
\end{abstract}

\section{Keywords}

FDI, WAEMU, Least Developed Countries, Fixed Effect, Financial Crisis

\section{Introduction}

Economic growth is a central question for every country. Despite the fact there are several contradictions among economists about how to grow the economy (classical theories, endogenous growth theories), they all agree that foreign capital plays an important role in the process of growing the economy. This external 
source of funding is relevant for both developed and least developed countries. More specifically for least developed countries, the very low amount of their national savings to finance investments is a typical economic problem. In fact, they constantly need foreign capital to prime their economic development. Those capitals can be either direct or indirect investments, or both.

Before 1980, it was possible for those countries to easily get loans from international institutions. However, since 1980, this mechanism was no longer possible, so that they have to make some reforms and more specifically about their investment policies in order to attract more stable and lasting capital inflows. A good source of foreign capital that is not risky regarding the country national debt is without any doubt the Foreign Direct Investment. It then became for many countries an alternative source of funding since the inaccessibility to international institutions funds.

For Agiomirgianakis et al. [1], FDI is mainly defined as capital flows arising from the behavior of multinational corporations (MNCs). And for Dunning [2], three factors (Ownership advantage, Location advantage, Internationalization advantage) can explain the reasons why an MNC decides to direct its investments to a specific given country. So countries FDI's magnitude and direction strongly depend on factors seen by investors as attractive. Many factors could explain the attractiveness of a country by investors and it is very important to detect those factors but also improve them to arouse the infatuation of investors.

Several studies have shown the potential factors that could be seen as attractive by investors. For instance, the $A D B^{1}$ (2004), stated that rapid technological progress, emergence of globally integrated production and marketing networks, existence of bilateral investment treaties, recommendations from multilateral development banks, and positive evidence from developing countries that have opened their doors to FDI are factors that have substantially accelerated FDI's direction.

From 1970 to 2007, the FDI flows in the world have increased dramatically from $\$ 13.3$ billion to $\$ 2.1$ trillion, followed by a decline two years later ( $\$ 1.1$ trillion in 2009) mainly due to the global financial crisis. However, Africa as a region has not benefited from the FDI boom. In fact, the FDI inflows to the continent represent a low share of global FDI and are on the downward trend. On the same period, Africa's share of global FDI inflows declined from 9.5 percent to 5.3 percent (World Bank, 2010).

FDI represents a potential solution to the continent's growth and development challenges. It provides the needed capital for investment, brings with it, employment, managerial skills, technology and at the end accelerates growth and development. The role of FDI is quite critical in Africa given the fact that poverty levels are generally high while domestic savings and incomes remain extremely low as income is mainly channeled to consumption expenditure. These factors coupled with the unpredictability of foreign aid flows, the low share of

\footnotetext{
${ }^{1}$ Asian Development Outlook.
} 
Africa in world trade and the high volatility of short-term capital flows call for the need to attract different forms of FDI inflows.

The West African Economic and Monetary Union (WAEMU) which is composed of eight least developed countries, sharing almost the same national language (French) and the same currency (CFA), is not on the sidelines of this reality. Prior to its creation, the countries members of this union experienced low growth, economic instability (high inflation), high external debt, couple of factors that seems to not play in their favor in attracting foreign capital. One of the main purposes in creating such union was to boost their economic performance by taking common actions and make it easier for foreign capital to flow in the region. But there is a big gap between the current state and the expectations.

In addition, the world has been shaken by a financial crisis in 2008. This crisis negatively impacted the world economy. Since the investors of the WAEMU mainly come from developed countries which have been severely affected by the crisis, it is paramount to pay attention on the consequences of the crisis on the Union's FDI and its determinants. Instinctively, we can assume that the pre-crisis and the post-crisis FDI's determinants will change considerably.

On the light of what have been mentioned above, the central question of our research is: what have been the effects of the 2008 financial crisis on the determinants of Foreign Direct Investments in the West African Economic and Monetary Union (WAEMU)?

With respect to this interrogation, the main objective of this article is to identify the determinants of FDI before and after the 2008 financial crisis, and to explain the gaps.

The main contribution of this article is twofold. First, studies have been already conducted to identify the determinants of FDI in the WAEMU, but to our knowledge, no research has tackled the effect of the financial crisis on those determinants. Secondly, the adoption of the panel data approach allows to better capture the effect of the crisis since countries do have specifities.

The remaining part of this article is organized as follows. A literature review that allow to capture not only the theoretical aspects of FDI, but also the results of past empirical studies. It is followed by the presentation of materials and methods that have been used, notably the sources of our data, the choice of variables, the presentation and justification of the model. After that, we present our empirical results and discuss them by confrontation with prior studies. In fine, the research ends up with a conclusion and eventually the proposition of economic policies. The main limitation of this article is the difficulty to find information about some variables which could possibly influence FDI.

\section{Review of Prior Studies}

Despite the growing importance of Foreign Direct Investments in economic, there is no unified theoretical framework for understanding the underlying determinants of their flows. Nonetheless, the magnitude of FDI flows around the 
world has attracted particular attention from many least developed countries which have invested heavily in empirical studies to better understand the phenomenon and certainly to have better control over it. This review tackles both FDI theories, but also confronts prior empirical results.

\subsection{Theoretical Approach to FDI}

Various and complementary theories have been put forward by authors to explain the flows of FDI in a specific location. In fact, the terminology FDI is not very recent in the literature. According to the neoclassical, the flows of FDI correspond to an adaptation of firms to the conditions of national and international markets in terms of factor costs resulting from factors endowments. According to their view, capital should therefore flow from countries where they are more abundant to those where they are relatively scarcer, because in those countries, yields of new investments should be higher.

Another theory on FDI was based on the Heckscher-Ohlin (1933) model to which two other models from MacDougall [3] and Kemp (1964) have been added to form a model known as MacDougall-Kemp model. According to this model, higher profitability in foreign market, labor cost and exchange risks are the key determinants for investing abroad. Since the apparition of this model, many other authors have developed some theories which sometime support or contradict the MacDougall-Kemp's model.

\subsubsection{Market Imperfection's Theory and Differentiation}

An imperfect market refers to any economic market that does not meet the rigorous standards of a hypothetical perfectly (or "purely") competitive market, as established by Marshellian partial equilibrium models. It arises whenever individual buyers and sellers can influence prices and production, or otherwise when perfect information is not known to all market actors. Hymer [4] and Kindleberger [5] believe that for FDI to occur, there must be some imperfections in the markets for either goods or factors of production. Hymer [4] also supports that ownership advantages such as innovative products, management skills, patents etc. are required to a given firm involved in FDI since doing business overseas is associated with a high cost of information related to the culture and language differences. Basing his study on the product differentiation, Caves [6] ended up with the conclusion that the product differentiation based on knowledge has as best entry mode FDI.

\subsubsection{Eclectic Paradigm or OLI (Ownership Location Internationalisation)}

Dunning [2] breaks with all the approaches that preceded him. He sees first that it is the existence of differentiable goods due to imperfect competition that is at the origin of the appearance of multinational firms. He then develops his famous global approach to explanatory factors for FDI: ownership-location-internalization (OLI), which is a paradigm because it reports at the same time contradictory theories. For him a MNC should choose FDI over all other kinds of market 
entrance mode if the criteria of Ownership advantages, Location advantages and Internationalization advantages are simultaneously met.

The Ownership advantages are related to the firm intrinsic capacity which can be measured in terms of its assets, patents, technologies or other types of advantages that are unique to the company [7]. The Location advantages concern factors that are not available in the domestic market and can be helpful for the company in lowering its costs or increasing its profit. Such factors are market size, special tax regimes or lower risk. Gillies [8] states that the choice of specific location is based on specific condition that are in the company favour. The Internationalization advantages are all kinds of advantages related to international business. Dunning [2] supports that internationalization can reduce the market imperfection.

\subsection{Empirical Evidence on the Determinants of FDI}

\subsubsection{Explanatory Factors to FDI's Inflow}

A large number of variables have been identified in the literature to explain FDI's inflow. Among them, some are just based on theories of FDI whereas other have been used for their instinctive explanatory power. Broadly speaking, most of the studies conducted carry out a few number of African countries and concentrated on the sub Saharan Africa but do not tackle the case of the WAEMU zone.

By using data compiled from 32 African countries over the period 1970 to 1999, Asiedu [9] [10] investigated whether developing and Sub Saharan African (SSA) countries FDI's inflows are driven by the same factors. She came to the conclusion that the impact of the factors is different. In fact, the infrastructure development only impacts positively non sub Saharan African countries. Concerning trade openness, the author established a positive and significant relationship with FDI for both sub and non-sub Saharan countries. Some authors like Kravis and Lipsey [11] and Edward [12] also found a strong positive linkage between FDI and openness. In contrast, Bieri [13] found that the linkage is positive but weak.

Onyeiwu and Shrestha [14] use data collected from 29 African countries from 1975 to 1999, where GDP growth, trade openness, international reserves and natural resources were explanatory variables to FDI. Their research has corroborated the theories supporting that the market size, openness and natural resources positively impact FDI inflows. Jordaan [15] also supports that market size is a strong determinant to FDI. For him FDI will move to larger and expanding markets' countries because in these countries, firms can receive a higher return. However, for Artige and Nicolini [16], market size and growth are the main determinants for horizontal FDI, but irrelevant in the case of vertical FDI.

For Krugell [17], not only the market size positively impacts FDI inflow, but so do the infrastructure and past FDI inflows. This evidence comes from his study conducted on 17 African countries over the time period 1980 to 1999. 
Suliman and Mollick [18] found new evidence of FDI in Africa. In the purpose of explaining the dependent variable FDI inflows/GDP, they have collected data from 29 SSA over 1980 to 2003 and found that literacy rate, freedom (political and civil right) and incidence of war are very important determinants to FDI.

Some authors also found that labor cost is an important determinant to FDI for developing countries. In fact, all other factors remaining unchanged, a low cost of labor would be profitable for the MNC since it reduces the production cost. Krugell [17] pointed out the positive benefit of cheap labor cost in attracting foreign investors. He also went further to underscore that wages should reflect productivity. In the same dynamic, Pigato [19] supports that FDI will be directed in countries with both cheap and qualified human capitals since the retraining cost of personnel with high educational background is low.

Finally, political instability is also associated with a low FDI inflow. Sichei and Kinyondo [20] argue that political instability and frequent occurrence of civil disorder are not favorable to the business climate in a country. They arise and strengthen the lack of confidence of risk averse investors. However, $O D I^{2}$ (1997) sees political instability as not a negative factor to FDI in African countries which own tremendous natural resources such as Nigeria, Angola etc. In those countries, the political risk is compensated by the high return in extractive industries.

\subsubsection{Relationship between FDI and Financial Crisis}

Beyond economic, social and political factors, financial crisis also impacts FDI for both home and host countries. Dornean et al. [21] in their study on the impact of the 2008 financial crisis on FDI for Central and East Europe countries through a panel approach found that the crisis considerably deteriorated FDI inflow in that region. However, the magnitude of the impact is different depending on the type of capital and country. In contrast, Ucal et al. [22] [23] conducted their study on the relationship between financial crisis and FDI in least developed countries. Comparing to the first authors, they used a semi parametric approach, but the conclusions converge: a drop of FDI volume has been the direct consequence of the crisis. Contrary, Kekic [24], thinks the impact of the financial crisis has been positive for developing countries. In fact, it has shifted FDI from developed countries to developing countries.

The impacts of the crisis of FDI are known. However, its effects on FDI's determinants have not been studied yet. This article has the merit to be the first one in tackling the effects of the crisis of FDI's determinants in the WAEMU.

\section{Data, Variables and Statistics}

This study is based on data collected from eight least developed countries, all members of the WAEMU. The data cover the period 1994 to 2016. The choice of ${ }^{2}$ Overseas Development Indicators. 
this time frame is due to the fact that the union has been created in 1994 and all our independents variables are lagged by one year. In addition, we could not get the data for 2017 at the time we were conducting the research.

The data on FDI inflow come from the United Nation Conference on Trade and Development (UNCTAD) database. The information related to inflation, GDP, GDP growth, foreign aids have been collected from the World Bank. Finally, data concerning natural resources, trade openness, labor cost, business environment, political stability, credit to private companies are from the Global Economy database. The resort to many databases is explained by the fact that all data could not be obtained from only one database.

\subsection{Dependent Variable}

The dependent variable in our model is the Foreign Direct Investment inward, and refers to direct investment equity flows in the reporting economy. It is the sum of equity capital, reinvestment of earnings, and other capital. Direct investment is a category of cross-border investment associated with a resident in one economy having control or a significant degree of influence on the management of an enterprise that is resident in another economy. Ownership of 10 percent $t^{3}$ or more of the ordinary shares of voting stocks is the criterion for determining the existence of a direct investment relationship. Data are in current U.S dollars.

\subsection{Independents Variables}

Prior empirical researchers have identified the market size as an important parameter for investors [25] [26]. To know its effect on FDI's inflow in the WAEMU, GDP at purchaser's price is used as a proxy variable and represents the sum of gross value added by all resident producers in the economy plus any product taxes, minus any subsidies not included in the value of the products. It is calculated without making deductions for depreciation of fabricated assets or for depletion and degradation of natural resources (World Bank). Data are in current U.S dollars. Beside the market size, its growth has also been identified as relevant factors to investors [26]. In our research, it is measured by the annual percentage growth rate of GDP at market prices based on constant local currency. Aggregates are calculated taking 2010 as based year. In addition to these factors, economic and political instability could negatively influence FDI inflows. In fact, Root and Ahmed [27] found that political instability impedes FDI inflows in least developed countries whereas Wheeler and Mody [28] concluded that this variable has no significant impact on the US FDIs. Concerning economic instability, Walsh and $Y u$ [29], have used inflation as a proxy variable and found that globally, economic instability has a positive impact on FDI. However, when taking into account the nature of FDI (primary, secondary and tertiary), the effect is negative. To detect the impact of these two factors on the WAEMU FDI's inflow,

${ }^{3}$ World Bank Criterion. 
the consumer's price index, which reflects the annual percentage change in the cost to the average consumer of acquiring a basket of goods and services is choose as a proxy for economic instability, and for political instability, we use the Civil Liberties index from the Freedom House. This variable evaluates the freedom of expression and belief, associational and organizational rights, rule of law, and personal autonomy and individual rights. The rating ranges from 1 (strong liberties) to 7 (no liberties).

For Mottaleb and Kalirajan [30], Foreign aids could mitigate a country's macroeconomic problems. So we believe that it has an explanatory power on FDI and is then put in our model. The sum of net official development assistance is used as a proxy. Net official development assistance (ODA) consists of disbursements of loans made on concessional terms (net of repayments of principal) and grants by official agencies of the members of the Development Assistance Committee (DAC), by multilateral institutions, and by non-DAC countries to promote economic development and welfare in countries and territories in the DAC list of ODA recipients. It includes loans with a grant element of at least 25 percent (calculated at a rate of discount of 10 percent). Furthermore, the host country openness to the global market could motivate efficiency seeking investors. Sing and Jun [31] found that a country oriented toward export attracts more investors. Therefore, following Walsh and $Y u$ [29], trade openness calculated as the ratio of total import and export over the GDP is added to our model.

Generally, least developed countries have comparative advantage in labor and have tremendous natural resources. In the frame of our research, because of the difficulties to obtain data on wages, we followed $A$ siedu [9] [10] by using the inverse of the real GDP per capita as a proxy to measure wages.

For the variable "natural resources", it corresponds to income from total natural resources as a percentage of GDP (Global Economy) which reflects the importance of natural resources in the host country. Mathematically, it is the sum of oil rents, natural gas rents, coal rents (soft and hard), mineral rents and forest rents.

Another important factor to investors is the business environment in the host country. Because of its explanatory power to FDI's inflow, the business environment is considered in the model, and measured by the Business Freedom Index which is based on 10 indicators, using data from the World Bank's Doing Business study: starting a business-procedures (number), time (days), cost (\% of income per capita), and minimum capital (\% of income per capita); Obtaining a license-procedures (number), time (days), and cost (\% of income per capita); Closing a business-time (years), cost (\% of estate), and recovery rate (cents on the dollar).

Moreover, the access to credit represents a source of diversification of financial risks for companies, and can then impel investors. It refers to financial resources provided to the private sector by other depository corporations (deposit taking corporations except central banks), such as through loans, purchases of 
non-equity securities, trade credits and other accounts receivable, that establish a claim for repayment. This variable is measured as a percentage of GDP.

The non-respect of the constitution (terms limit) could be seen by foreign investors as a stepping corner to political instability in the medium or long run. This dummy variable is added to the model to see whether the president tenure affects foreign capital inflow. It takes the value 1 if a president has been in the power for more than two terms $s^{4}$ and 0 otherwise.

\subsection{Summary Statistics}

The summary statistics shows that the mean value of FDI in the WAEMU is about $\$ 178$ million with a very high variation ( $\$ 210$ millions). We can also notice that in average, economic growth and inflation are low in the region $(4.08 \%$ and $4.48 \%$ respectively). Nonetheless, these numbers hide some disparities because the maximum value of economic growth is a two-digit number (15.37\%) and the inflation is amounted to $50 \%$. In addition, we can see that for a large number of variables, the skewness is close to zero, which is a characteristic of a normal distribution. However, the Jarque-Bera probabilities tell us that our data are not normally distribution, which could have some incidence on our econometrics tests (Table 1).

\section{Materials, Methods and Model Specification}

Several of the previous studies adopted the panel estimation method [32]. This method has the double advantage of examining both the spatial dimension and the temporal dimension. In a panel regression, the estimation of the coefficients

Table 1. Summary of descriptive statistics.

\begin{tabular}{|c|c|c|c|c|c|c|c|c|}
\hline Variables & Mean & Median & Min & $\operatorname{Max}$ & Std. Dev & Skewness & Kurtosis & Jarque-Bera \\
\hline$F D I_{t}$ & $178 \mathrm{M}$ & $0.78 \mathrm{~B}$ & $19.14 \mathrm{M}$ & $1.07 \mathrm{~B}$ & $210 \mathrm{M}$ & 1.7 & 6.02 & $150(* * *)$ \\
\hline $\ln G D P_{t-1}$ & 22.12 & 22.23 & 19.14 & 24.28 & 1.10 & -0.55 & 3.06 & $9.04(* * *)$ \\
\hline$R G D P_{t-1}$ & 4.08 & 4.17 & -28.09 & 15.37 & 4.08 & -2.810 & 25.683 & $3640.91\left(^{* * *}\right)$ \\
\hline$T R O P N_{t-1}$ & 62.22 & 59.93 & 30.51 & 125.03 & 17.99 & 0.61 & 3.09 & $11.11\left(^{* * *}\right)$ \\
\hline $\ln W A G E_{t-1}$ & -6.14 & -6.18 & -7.34 & -5.07 & 0.54 & -0.00 & 2.15 & $5.19\left(^{*}\right)$ \\
\hline$N A T R E S_{t-1}$ & 9.35 & 8.58 & 2.46 & 31.62 & 5.11 & 1.16 & 4.75 & $61.83\left({ }^{* * *}\right)$ \\
\hline$B U S E N V_{t-1}$ & 49.59 & 52 & 23 & 70 & 11.06 & 0.01 & 2.50 & 1.80 \\
\hline$F O R A I D S_{t-1}$ & $540 \mathrm{M}$ & $440 \mathrm{M}$ & $46.09 \mathrm{M}$ & $2.89 \mathrm{~B}$ & $420 \mathrm{M}$ & 1.70 & 8.51 & $306(* * *)$ \\
\hline$E \operatorname{COSTA} B_{t-1}$ & 4.48 & 2.48 & -3.5 & 50 & 8.82 & 3.34 & 14.92 & $1363(* * *)$ \\
\hline$C R E D P R I V_{t-1}$ & 14.01 & 13.53 & 00 & 37.71 & 7.34 & 0.69 & 3.76 & $18.24\left({ }^{* * *}\right)$ \\
\hline$D U M M Y P R E S_{t}$ & 0.29 & 0 & 0 & 1 & 0.45 & 0.88 & 1.78 & $33.69\left({ }^{* * *}\right)$ \\
\hline
\end{tabular}

${ }^{4}$ The two terms refer to 10 years in countries where the term is 5 years and 14 in those where the term is 7 years. 
of the explanatory variables is based on both the correlation of the variations "within" (temporal) and "between" (spatial). But with respect to the coefficient of a variable as well as its significance, the results do not allow us to dissociate the spatial dimension from the temporal dimension. The fact that an explanatory variable is strongly correlated with FDI on the temporal dimension does not mean this variable is a determinant of the spatial distribution. Therefore, it has disadvantages because if a study is to identify only the determinants of the spatial distribution of FDI, this "advantage" becomes a disadvantage.

In addition, the method of fixed panel estimation does not allow the introduction of variable that does not vary across time (such as distance). However, we consider that the panel estimation is a good method for our research because we seek to identify the determinants of FDI in space and time in the WAEMU zone, and our model does not contain any fixed explanatory variable. Therefore, in our study, we will carry out analysis on panel data.

Since our study is based on row data, we first take the natural log of all the independent variables which are not express in terms of rate or index, namely GDP and Wage. Doing so, the coefficients we obtain can be interpreted as semi-elasticity. Also, it takes a certain time between the changes in the explanatory variables and the decision to invest. That is why all the independent variables are lagged by one period. The general model to be estimated can then be written as:

$$
\begin{aligned}
\text { FDIit }= & \beta 0+\beta 1 \ln \text { GDPit }-1+\beta 2 \text { RGDPGit }-1+\beta 3 \text { TROPNit }-1+\beta 4 \ln \text { WAGEit }-1 \\
& +\beta 5 \text { NATRESit }-1+\beta 6 \text { BUSENVit }-1+\beta 7 \text { FORAIDSit }-1+\beta 8 \text { POLSTABit }-1 \\
& +\beta 9 \text { ECOSTABit }-1+\beta 10 \text { CREDPRIVit }-1+\beta 11 \text { DUMMYPRESit }+ \text { Eit } .
\end{aligned}
$$

where $\ln G D P$ is the natural $\log$ of national wealth lagged by one period. $R G D P$ the growth rate of GDP. TROPN and $\ln W A G E$ are respectively variable to capture the effect of trade openness and labor cost (salary). NATRES represents Natural resources, $B U S E N V$ is a variable to identify the impact of the business environment. FORAIDS is the contribution of foreign aids, POLSTAB and $E C O S T A B$ respectively represent political stability and economic stability. $C R E D P R I V$ corresponds to the ratio credit to private companies as percentage of GDP. Finally, DUMMYPRES is a dummy variable to see the effect of the president tenure on FDI.

Given that our work focuses on panel data, the first test that needs to be done is the test of specification of homogeneity or heterogeneity. Economically, this test serves to see if the theoretical model studied is perfectly identical for all the countries in the sample, or if there are specificities among countries. Econometrically, this means to check the equality of the coefficients of the model studied in the individual dimension. The Hausman test allows to check whether to use the fixed effect or the random effect model. Because the number of independents variables (11) is larger than the number of cross-section, we split the general model into two equations with respect to the economic dimension and the business environment dimension. Yet, all other econometric tests will be carried out following the general model. 


\section{Equation (1): Economic variables}

FDIit $=\beta 0+\beta 1 \ln$ GDPit $-1+\beta 2$ RGDPGit $-1+\beta 3$ ECOSTABit $-1+\beta 4$ CREDPRIVit -1 $+\beta 5$ TROPNit $-1+\beta 6 \ln$ WAGEit $-1+\beta 7 N A T R E S i t-1+\varepsilon i t$.

\section{Equation (2): Business environmental variables}

$$
\begin{aligned}
\text { FDIit }= & \beta 0+\beta 1 \text { POLSTABit }-1+\beta 2 \text { BUSENVit }-1 \\
& +\beta 3 \text { FORAIDSit }-1+\beta 4 \text { DUMMYPRESit }+ \text { eit } .
\end{aligned}
$$

The test shows (Table 2) that all the prob are less than 5\%, which imply that the fixed effect model is suitable for our econometric tests. The different estimations are carried out following this model.

\section{Empirical Results and Discussion}

\subsection{Empirical Results of FDI Determinants in the Union}

Our econometrics results show that over the horizon 1994-2016, FDI inflows are influenced by many variables. In fact, the fixed effect model for cross-sections and times allows to identify only two variables that are not significant (trade openness and business environment). However, when ignoring the time effect, to these two variables mentioned above, is added economic growth, natural resources and the cost of labor.

The significance of the coefficient of lnGDP shows that FDI is strongly sensitive to the market size, and its sign indicates that there is a positive linkage between the evolution of national wealth and investor's attraction. In the case of our research, a $1 \%$ increase in the market size leads to increase FDI inflow by $11 \%$. Under the hypothesis that GDP measures the market size, we can conclude that a large number of investors in the region are market seeking investors. This result corroborates the eclectic paradigm and the empirical results of Jordaan [15] stating that FDI will flow to countries with larger and larger market size. It is also aligned with the conclusion of the UNCTAD which supports that when opting for FDI decisions, firms seek for markets with large opportunities (market seeking FDI motives).

Paradoxically, economic growth in the union has a negative and significant effect on FDI. That can be explained by the fact that the growth in the region is not self-preserved. In fact, it varies as time goes by. This is captured by investors as an instability of growth, which does not allow to conduct some forecasting. Furthermore, this growth is weak for least developed countries ( $4 \%$ on average). This number might be interesting for developed countries, but very weak for countries that aspire to development.

The variable "natural resources" impacts negatively and significantly FDI inflow in the region. This result is the consequence of a weak contribution of natural resources to the GDP in the union. In fact, this contribution varies between $2.46 \%$ to $31.62 \%$ with a median value of $8.58 \%$. Since the union's GDP is weak, these percentages indicate that the exploitation of natural resources does not generate high income, which does not make the union attractive for resource seeking investors. 
Table 2. Hausman specification test.

\begin{tabular}{cccc}
\hline Test Summary & Chi-Sq. Statistic & Chi-Sq. d.f. & Prob. \\
\hline Cross-section random (Equation (1)) & 49.876912 & 7 & 0.0000 \\
Cross-section random (Equation (2)) & 21.418726 & 4 & 0.0003 \\
\hline
\end{tabular}

The political stability (measured by inflation) and the cost of labor (measured by the real GDP per capita) play positively on FDI. These results are against the expectation. In theory, a low inflation and a cheap labor force must affect positively FDI. The evidence from our research state otherwise. A $1 \%$ increase in these variables leads to increase FDI respectively by $0.04 \%$ for inflation and $9.22 \%$ for wage. Although significant, the impact of inflation is marginal. Concerning the labor cost, its positive sign implies that an improvement in employee's remuneration increases their motivation, and, as consequence, arises their productivity. This is then captured positively by foreign investors.

The effect of the variable "polstab" on FDI must be interpreted carefully. In fact, since it is a bounded index, a high value given to this variable is source of instability. Our results corroborate prior studies and support that instability in the union impedes FDI inflow. This result is however contrary to ODP (1997) conclusion which supports that political instability is not a negative factor to FDI when the country is endowed with tremendous natural resources.

Against all expectation, the variable "credit to privates" does not give the expected sign. It influences negatively and significantly FDI. This result can be understood as the consequences of difficulties to access credit. In the case of the WAEMU, the average contribution of credit to private sector is about $14 \%$ with a maximum of $37 \%{ }^{5}$, whereas this ratio is more than $80 \%$ in developed countries such as US, France ...

Finally, the president tenure strongly discourages foreign investors. The research supports that after two terms, the reelection of the president reduces FDI inflow by more than $50 \%$. This result is in fact an anticipation by investors to the political destabilization in the future which creates a bad business environment (Table 3).

\subsection{Effect of the 2008 Crisis on FDI's Determinants in the WAEMU}

As the 2008 financial crisis has shaken the financial world, and since investments in Africa mainly come from developed countries which have been negatively affected, it is fundamental to analyze its impact on FDI in the goal of proposing some economic policies.

The regression shows that before and after the crisis, FDIs were positively sensitive to the national wealth. However, this variable only influences significantly FDI after the crisis. Reversely, natural resources were not significant before the crisis, but FDI became sensitive to this variable after the crisis. These results show that one of the consequences of the crisis has been an effect of subs- 
titution of determinants. In fact, the crisis chased away market seeking investors, and called resource seeking investors. A possible explanation is that post crisis, the traditional sectors of opportunities were no longer attractive except natural resources (Goal, Iron, Manganese) for which the exploitation could generates substantial income for investors. The variable "political stability" is also negatively linked to FDI in the WAEMU, but significant only after the crisis. That shows how careful investors of the region became in committed their funds after crisis. However, the president tenure identified as a potential precursor to political destabilization has no impact on FDI post crisis (Table 4).

\subsection{Robustness Test}

In a new regression, we check the robustness of our estimates to see whether they vary according to the proxy used. In that purpose, we use three new variables (economic globalization index, Political globalization index and social globalization index) as proxy to see their effect on FDI. In addition, trade openness is now measured by the part of import to the GDP (TROPN2) since the union is a big importer; and by export to GDP (TROPN3).

The economic globalization has two dimensions: actual economic flows and restrictions to trade and capital. The sub-index on actual economic flows includes data on trade, FDI, and portfolio investment. The sub-index on restrictions takes into account hidden import barriers, mean tariff rates, taxes on international trade (as a share of current revenue), and an index of capital controls. The degree of political globalization is determined by the number of embassies and high commissions in a country, the number of international organizations to which the country is a member, the number of $\mathrm{UN}$ peace missions a country participated in, and the number of treaties signed between two or more states. And finally, social globalization has three dimensions: personal contacts, information flows, and cultural proximity. The sub-index on personal contacts includes international telecom traffic, degree of tourism, transfers, foreign population, and number of international letters. The sub-index on information flows includes number of internet users, share of households with a television set, and trade in newspapers. The sub-index on cultural proximity includes trade in books and number of McDonald's restaurants and Ikea located in a country.

The estimation shows (Table 5) that trade openness measured by the contribution of imports to the GDP (TROPN2) and trade openness measured by the contribution of export to the national wealth (TROPN3) contrary to the variable $T R O P N$ is significant after crisis. This result implies that FDI is strongly sensitive to this variable. So we can identify a third category of investors in the region: the efficiency seeking investors. In fact, these investors do not seek only to maximize the profit in the region they are, but to use it as a steeping corner to access other market.

Concerning the three global indices, only the economic globalization index is not statistically significant. The political globalization index impacts positively 
and significantly FDI post crisis. This result corroborates those obtained in Table 4 which state that an instable area impedes FDI inflows.

For the social globalization index, it impacts significantly FDI at 1\% level, but differently before and after the crisis. Considered to be a determinant of FDI on the pre-crisis horizon, this variable is an impediment factor after crisis.

Table 3. Determinants of FDI with fixed effect method.

\begin{tabular}{ccc}
\hline Variables & $\begin{array}{c}\text { Coefficients } \\
\text { (two ways fixed effect })\end{array}$ & $\begin{array}{c}\text { Coefficients } \\
\text { (no time fixed effect })\end{array}$ \\
\hline InGDP & $-177.95450^{* * *}$ & $-47.52627^{* * *}$ \\
RGDPG & $11.56300^{* * *}$ & $3.635699^{* * *}$ \\
TROPN & $-0.049434^{* *}$ & -0.025207 \\
FORAIDS & 0.008292 & 0.007275 \\
NATRES & $-6.53 \mathrm{E}-10^{* *}$ & $-6.53 \mathrm{E}-10^{* *}$ \\
ECOSTAB & $-0.073002^{* *}$ & -0.033008 \\
POLSTAB & $0.040989^{* * *}$ & $0.028819^{* * *}$ \\
InWAGE & $-0.333901^{* *}$ & $-0.277575^{* *}$ \\
CREDPRIV & $9.226611^{* * *}$ & 1.949635 \\
BUSENV & $-0.077747^{* * *}$ & $-0.051719^{* *}$ \\
DUMMYPRES & -0.000958 & -0.014306 \\
R-squared & $-0.627491^{* *}$ & $-0.879148^{* * *}$ \\
Adjusted R-squared & $\mathbf{0 . 8 2 7 2 7 0}$ & $\mathbf{0 . 7 8 6 9 5 7}$ \\
\hline
\end{tabular}

***; **; $*$ are respectively $1 \%, 5 \%$, and $10 \%$ significance level.

Table 4. Determinants of FDI before and after the 2008 financial crisis.

\begin{tabular}{ccc}
\hline Variables & Before the crisis & After the crisis \\
\hline$C$ & $-44.84296^{* *}$ & 6.717168 \\
InGDP & $3.506417^{* *}$ & 1.154081 \\
RGDPG & -0.030018 & -0.011740 \\
TROPN & -0.008136 & 0.016534 \\
FORAIDS & $-7.26 \mathrm{E}-10$ & $-2.61 \mathrm{E}-10$ \\
NATRES & -0.055699 & $0.089324^{*}$ \\
ECOSTAB & $0.034968^{* * *}$ & -0.016007 \\
POLSTAB & -0.221910 & $-0.386290^{*}$ \\
InWAGE & 1.729501 & 2.174893 \\
CREDPRIV & $-0.071595^{* *}$ & -0.028483 \\
BUSENV & -0.011727 & 0.011317 \\
DUMMYPRES & $-1.329757^{* * *}$ & 0.859500 \\
R-squared & $\mathbf{0 . 7 9 1 0 1 4}$ & $\mathbf{0 . 8 1 0 5 8 1}$ \\
Adjusted $R$-squared & $\mathbf{0 . 7 1 5 8 7 1}$ & $\mathbf{0 . 7 5 3 3 9 6}$
\end{tabular}

${ }^{* * *} ;{ }^{* *} ;{ }^{*}$ are respectively $1 \%, 5 \%$, and $10 \%$ significance level. 
Table 5. FDI's determinants with global indices and new measurement of trade openness.

\begin{tabular}{ccc}
\hline Variables & pre-crisis Coefficients & post-crisis Coefficients \\
\hline C & $16.98781(0.0000)^{* * *}$ & $14.18263(0.0000)^{* * *}$ \\
ECOGLOBINDEX & $-0.057868(0.0034)^{* * *}$ & $0.004988(0.7493)$ \\
SOCGLOBINDEX & $0.047000(0.0815)^{*}$ & $-0.117397(0.0000)^{* * *}$ \\
POLGLOBINDEX & $0.013708(0.1874)$ & $0.075978(0.0000)^{* * *}$ \\
TROPN2 & $-0.004448(0.8449)$ & $0.047943(0.0002)^{* * *}$ \\
TROPN3 & $0.493711(0.0000)^{* * *}$ & $0.138085(0.0003)^{* * *}$ \\
R-squared & $\mathbf{0 . 4 7 6 6 4 3}$ & $\mathbf{0 . 7 6 1 7 4 5}$ \\
Adjusted R-squared & $\mathbf{0 . 4 5 3 4 8 5}$ & $\mathbf{0 . 7 3 3 3 8 1}$ \\
\hline
\end{tabular}

***;**; ${ }^{*}$ are respectively $1 \%, 5 \%$, and $10 \%$ significance level.

\section{Conclusion and Policy Implications}

Over the course of the last 22 years, the West African Economic and Monetary Union created in the goal of economic integration has put forward many policies to attract foreign investors. That was one of the goals of the union. But to this day, it is clear that on this point (attract FDI), the union has failed because the inflow of foreign capital remains low. The main objective of this article was to figure out what have been the effects of the 2008 financial crisis on WAEMU FDI's determinants. In that purpose, our research has used data from World Bank, the United Nation Conference on Trade and Development and the Global Economic databases.

Because of the interest for both temporal and spatial dimension, we have used panel approach. From the research, it turns out that the crisis has strongly impacted many determinants in the union. More specifically, it leads to chase out market seeking investors, and appealed resource seeking investors. In addition, our robustness tests underlined the presence of a third type of investors in the region: the efficiency seeking investors. Furthermore, the three indices show a variability of coefficients with respect to the proxy used. In fact, the effect of the crisis is not the same when economic stability is measured by global economic index as inflation. However, concerning political stability, the proxy used does not change the conclusion: political stability influenced positively FDI after the crisis.

With respect to the variables that have been impacted by the crisis, our research implies the following policies.

First of all, a better management of natural resources is paramount, because the crisis has shown that despite a small market size, a country can still attract FDI if it has tremendous natural resources. For instance, the average contribution of natural resources to GDP in Burkina Faso was 8.85\% before the crisis with a corresponding FDI inflow amounted to 46.64 million. However, on the post crisis period, when the GDP stagnates ( $\$ 11$ billions) and the contribution of natural resources has doubled, the average amount of FDI inflow has been mul- 
tiplied by 5 ( 249.39 millions).

The same information shows that the average contribution of natural resources is marginal for Benin and in a downward trend. As a consequence, the volume of FDI in this country has dropped just after the crisis from 169 million in 2008 (134 million in 2009, 161 million in 2011) to 160 million in 2016. So policies makers should pay more attention to this variable. In addition, the post crisis period has also been characterized by much more precaution of investors with respect to the stability of area they invest. That implies if the WAEMU wants to attract more and more foreign capital, they have to promote democracy, a good political governance, and reinforce liberties (associational, organizational, freedom of speech and belief) because these factors are generally the roots of political instability. Furthermore, the union should better its degree of openness to the global market, because the possibility for investors to export their products beyond the borders of the country they are constitutes an important decisional factor.

Artige and Nicolini [16] suggest that market size and growth drive horizontal FDI but not vertical FDI. As future research, one can investigate what has been the impact of the crisis on the determinants of horizontal FDI and vertical FDI in the union.

\section{Conflicts of Interest}

The authors declare no conflicts of interest regarding the publication of this paper.

\section{References}

[1] Agiomirgianakis, G., Asterious, D. and Papathoma, K. (2003) The Determinants of Foreign Direct Investment: A Panel Data Study for the OECD Countries (Report No. 03/06). Department of Economics, City University London, London.

[2] Dunning, H.J. (2002) Determinants of Foreign Direct Investment: Globalization Induced Changes and the Role of FDI Policies. Annual World Bank Conference on Development Economics, Europe 2003: Toward Pro-Poor Policies-Aid, Institutions, and Globalization, Oslo, 24-26 Jun 2003, 279-290.

[3] MacDougall, G.D.A. (1960) The Benefits and Costs of Private Investment from Abroad: A Theoretical Approach. Economic Record, 36, 13-35. https://doi.org/10.1111/j.1475-4932.1960.tb00491.x

[4] Hymer, S. (1976) The International Operations of National Firms: A Study of Direct Foreign Investment. MIT Press, Cambridge.

[5] Kindlerberger, P. (1969) American Business Abroad. Thunderbird International Business Review, 11, 11-12.

[6] Caves, E.R. (1971) International Corporations: The Industrial Economics of Foreign Investment. Economica, 38, 1-27. https://doi.org/10.2307/2551748

[7] Dunning, H.J. and Lundan, M.S. (2008) Multinational Enterprises and the Global Economy. Edward Elgar Publishing, Jan 1, 2008, Business \& Economics, 920 p.

[8] Gillies, I. (2005) Transnational Corporation and International Production: Concepts, Theories and Effect. 
[9] Asiedu, E. (2002) On the Determinants of Foreign Direct Investment to Developing Countries: Is Africa Different? World Development, 30, 107-119. https://doi.org/10.1016/S0305-750X(01)00100-0

[10] Asiedu, E. (2006) Foreign Direct Investment in Africa: The Role of Natural Resources, Market Size, Government Policy, Institutions and Political Instability. United Nation University, Tokyo.

[11] Kravis, B.I. (1982) The Location of Overseas Production and Production for Export by U.S. Multinational Firms. Journal of International Economics, 12, 201-223. https://doi.org/10.1016/0022-1996(82)90036-8

[12] Edward, S. (1990) Capital flows, Foreign Direct Investment, and Debt-Equity Swaps in Developing Countries. Working paper N0. 349, National Bureau of Economic Research, Cambridge, MA.

[13] Bieri, J. and Schmitz, A. (1972) EEC Tariffs and U.S. Direct Investment. European Economic Review, 3, 259-270.

[14] Onyeiwu, S. and Shrestha, H. (2004) Determinants of Foreign Direct Investment in Africa. Journal of Developing Societies, 20, 89-106. https://doi.org/10.1177/0169796X04048305

[15] Jordaan, A.J. (2004) Estimating FDI-Induced Externalities When FDI Is Endogenous: A Comparison between OLS and IV Estimates of FDI-Induced Externalities in Mexico. London School of Economics, London.

[16] Artige, L. and Nicolini, R. (2006) Evidence on the Determinants of Foreign Direct Investment. The Case of Three European Regions. HEC-Management School, University of Liège, Liège.

[17] Krugell, W. (2005) The Determinants of Foreign Direct Investment in Africa. North-West University, South Africa. https://doi.org/10.1007/3-7908-1610-8_4

[18] Suliman, A. and Mollick, A. (2009) Human Capital Development, War and Foreign Direct Investment in Sub-Saharan Africa. Journal Oxford Development Studies, 37, 47-61. https://doi.org/10.1080/13600810802660828

[19] Pigato, M. (2001) Information and Communication Technology Poverty, and Development in Sub-Saharan Africa and South Asia. Africa Region Working Paper Series Number 20.

[20] Sichie, M.M. and Kinyondo, G. (2012) Determinant of Foreign Direct Investment in Africa: A panel Data Analysis. Global Journal of Management and Business Research, XII, Issue XVIII Version 1.

[21] Dornean, A., Isan, V. and Oanea, D. (2012) The Impact of Current Crisis on Foreign Direct Investment, Evidence from Romania. Revista Economica, Supplement, Issue 1, 266-273.

[22] Ucal, S.M. Ozcan, K.M., Bilgin, M.H. and Mungo, J. (2010) Relationship between Financial Crisis and Foreign Direct Investment in Developing Countries Using Semi parametric Regression Approach. Journal of Business Economics and Management, 11, 20-33. https://doi.org/10.3846/jbem.2010.02

[23] Ucal, S.M. (2014) Panel Data Analysis of Foreign Direct Investment and Poverty from the Perspective of Developing Countries. Procedia-Social and Behavioral Sciences, 109, 1101-1105. https://doi.org/10.1016/j.sbspro.2013.12.594

[24] Kekic, L. (2009) The Global Economic Crisis and FDI Flows to Emerging Markets. Vale Columbia Center on Sustainable International Investment.

[25] Resmini, L. (2000) The Determinants of Foreign Direct Investment in the CEECS: New Evidence from Sectoral Patterns. The Economics of Transition, 8, 665-689. 
https://doi.org/10.1111/1468-0351.00060

[26] Bevan, A.A. and Estrin, S. (2004) The Determinants of Foreign Direct Investment into Europe Transition Economies. Journal of Comparative Economics, 32, 775-787. https://doi.org/10.1016/j.jce.2004.08.006

[27] Root, R.F, and Ahmed, A.A. (1979) Empirical Determinants of Manufacturing Direct Foreign Investment in Developing Countries. Economic Development and Cultural Change, 27, 751-767. https://doi.org/10.1086/451139

[28] Wheeler, D. and Mody, A. (1992) International Investment Location Decision: The Case of U.S Firms. Journal of International Economics, 33, 57-76. https://doi.org/10.1016/0022-1996(92)90050-T

[29] Walsh, P.J. and Yu, J. (2010) Determinants of Direct Foreign Investment: A Sectorial and Institutional Approach. IMF Working Paper.

[30] Mottaleb, A.K. and Kalirajan, K. (2013) Determinants of Foreign Direct Investment in Developing Countries: A Comparative Analysis. ASARC Working Paper.

[31] Sing, H. and Jun, W.K. (1996) Some New Evidence on Determinants of Foreign Direct Investment in Developing Countries. World Bank Policy Research Paper N.1531.

[32] Zarzour, J.B.F. (2006) Determinants of Foreign Direct Investment in the WAEMU. Ph.D. Thesis, PTCI. 